\title{
The Role of Private Universities in Higher Education of Bangladesh: An Empirical Investigation
}

\author{
K. M. Anwarul Islam ${ }^{1}$, Umme Salma ${ }^{2}$ \\ ${ }^{1}$ Department of Business Administration, The Millennium University, Dhaka, Bangladesh \\ ${ }^{2}$ Department of Computer Science and Engineering, Bangladesh University, Dhaka, Bangladesh \\ Email address: \\ ai419bankingdu@gmail.com (K. M. Anwarul Islam), ummesalma.cse@gmail.com (U. Salma)
}

\section{To cite this article:}

K. M. Anwarul Islam, Umme Salma. The Role of Private Universities in Higher Education of Bangladesh: An Empirical Investigation. International Journal of Finance and Banking Research. Vol. 2, No. 4, 2016, pp. 121-128. doi: 10.11648/j.ijfbr.20160204.11

Received: January 23, 2016; Accepted: May 17, 2016; Published: June 30, 2016

\begin{abstract}
An exploratory survey was conducted to the role of private universities in higher education of Bangladesh. This research paper examines that private universities in Bangladesh, no doubt have contributed to responding to social demand for higher education by absorbing a good number of students who otherwise could not have received university degrees. The sample was taken on a random basis from about six private universities in the Dhaka metropolitan area. The results of this study show that contribution or role of private universities for the task of nation-building and reforming the education sector.
\end{abstract}

Keywords: Higher Education, Role of Private University, Bangladesh

\section{Introduction}

Environmental education is the most discussed subject in the present time. It becomes the central issue not only for Bangladesh context as well as in the international debate in the early part of twenty first century. The land, water, air, sea, ocean, hill, mountain, roads, transport, industry and its sound, human, animals, insects, trees etc. consisting of whole environment. The development \& survival of human fully depend on the peaceful and balanced coexistence of the environment. But most regretfully, the human society is destroying the equilibrium of nature by changing and mishandling the mineral resources. As a result the human society is facing the natural disasters with certain intervals. Therefore it is essential to rethinking that a good arranged structure for a historical study is significant in respect of environmental education in higher studies. Though there were environmental educations at the higher level in a scare and scattered way since 1970s, however, it was structured and developed after 1992. That's why the paper emphasizes a historical overview of the environmental education in higher studies in Bangladesh from 1992 to 2015.

Distinguished economists and scientists have alluded to the importance of the growth of human knowledge through formal educational processes that plays significant role in the development of the economy of Bangladesh. Education is, of course, an investment for the future. A country that deliberately devotes a pro-portion of its resources for education and to improve the skills and abilities of its young people expects to see change in its economic and social performance in the years ahead. Education is seen as the essential factor for rapid economic growth and formal education controlled by the state as the indispensable instrument for improving the productive capacities of a population.

Education or human resource development is termed as a powerful tool in achieving the economic development by providing the people with the necessary skills upon which development depends on. It spreads opportunity and creates hope, having a leveling and equalizing effect on society and creating a new class of persons owing their position to education and ability rather than birth. Actually, the purpose of education is to bring economic, social, political, cultural development and also mental, environmental, physical development of human being. It brings changes in human behavior and social mobility. It is the best investment for human being. The public sector institutions of the country are in utter disarray. Regularly increasing demand and inadequate facilities, and additionally the absence of conducive atmosphere in the campuses are driving away large number of students every year to our neighboring 
country and elsewhere. And, of course, those who can afford are going, and the rest leave their future on to their lucks. In such a frustrating situation, creating private sector facilities, under the provision of the Private University Act-1992, has brought a great relief for the students and their parents or guardians.

Traditionally there has been little competition within higher education systems and it is believed that more intense competition between similar institutions for faculty, students, and resources will help improve standards by rewarding merit and performance. Competition also generally promotes beneficial innovations and overall quality improvements. It is also important to note that competition is exceedingly difficult to achieve through central decree, but requires a high degree of autonomy for academic institutions, allowing them to exploit their strength and overcome weaknesses. Adequate market information is also essential; without it, institutions will continue to thrive even when are weak. Service markets, and in particular educational provider markets, have changed significantly in the last 23 years in Bangladesh. Education providers in Bangladesh face intense competition and must, therefore, take a vigorous approach to marketing. As the importance of higher education increases more and more, it becomes absolutely essential to formulate its overall objectives and goals, content, organization and strategies etc. It is important to integrate marketing into the everyday business of education provision, although marketing is frequently seen as difficult by education providers in Bangladesh.

Universities in Bangladesh play very important role in the overall development of the country. This is evident from the fact that the students and teachers of the Dhaka University which was established in the year 1921, was at the forefront of the national liberation struggle that led to the independence of the country. Other Universities of Bangladesh at both public sector and the private sector are also playing important role by not only providing degrees and thus producing quality human resources for various sectors of the economy, but also producing enlightened citizens and thus improving the quality of life in the society as a whole.

In order to solve the problem of accessibility of higher education the government of Bangladesh is allowing the establishment of private Universities in Bangladesh from 1992. However the University Grant Commission of Bangladesh would have the power to approve or reject the establishment of private Universities in Bangladesh. There are at present 85 private Universities in Bangladesh.

The University Grant Commission of Bangladesh would in fact be responsible for supervising and maintaining the quality of education in all the public and private Universities of Bangladesh, as it is the statutory apex body in the field of higher education in Bangladesh. Therefore it advises the govt. to improve the quality of higher education system in Bangladesh. It performs such other important functions like determining the financial needs of the Universities and disbursing the grants for their maintenance and development.

\section{Scenario of Higher Education in Bangladesh}

Most of the higher education's providing institutions in the developing world are in the public sector. They are built, financed and staffed by the government. Since about 1950 there has been a rapid acceleration in the rate of growth of demand for educational services at all levels, the most notable at the level of higher education in the college and university level. In Bangladesh the demand for educational services started increasing since early $80 \mathrm{~s}$. As per Bangladesh Bureau of Statistics, in 1992 the number of medical colleges, engineering colleges and universities were 17 (Govt. 13, Non Govt-4), all Govt. and 17 (Govt. 11. non govt. 6) respectively. But only a small percentage of these students get the opportunity for higher education in the country. Besides, vast majority of those having higher education cannot find job opportunity. These clearly indicate the discrepancy between the need and the resources. This is not the whole truth. The education offered today is vastly non-productive. Hence, the existing educational system has produced a large population of educated unemployed.

At present, there are 132 universities in Bangladesh of which 95 are private and 37 are public. With the expansion of education facilities in secondary and higher secondary level the demand for higher education has increased dramatically in recent years. The public higher institutions were not successfully meeting this pressure. To meet this demand and reduce the increasing cost at the higher level, government opened the opportunity for private sector participation in higher education. As a result, the number of students in the private universities is increasing day by day. The private universities in Bangladesh recorded a phenomenal growth after the enactment of the Private University Act in 1992. Both public and private sector institutions are providing higher education. Though some questions are here about the quality of education, it makes a competitive environment in higher education. This interaction and competition opens a space to enhance the quality of higher education.

It is now an admitted fact that no Government can employ all educated people both in the developing and the developed countries. While a country needs a large number of technically qualified persons in the various fields, the number of this group is far too small to satisfy the need of the country. This is applicable for all branches of technical education e.g. medical, engineering, agricultural, pharmaceutical, business studies. In fact in all technical branches need many more qualified personnel than are available today. And yet avenues for education in these specific fields are limited. As a result, the number of Bangladeshi students studying abroad is almost three times more than the number studying in all our Universities, Engineering and Medical Colleges. These are the rich and the privileged groups. They do not suffer the consequences and in fact they take it as a pride to send their boys and girls for studies abroad. Not even for moment they think how much they are depriving the country of the hard earned foreign exchange and degrading the prestige of the 
nation in the eyes of the outside world. What is even more important is that the outcomes of such ventures are nothing less than fatal for the country. Most of these students who are trained abroad are a great loss for the nation and some of them even hesitate to identify themselves as Bangladeshis. Bringing up in a different cultural environment where family link is too loose and the religious bondage is very weak it is rather too much to think of bringing them back to their homeland.

\section{Literature Review}

The positive role of private Universities in the higher education in Bangladesh is now undeniable (Siddique 2005). The epoch-making Private University Act was passed in 1992 To meet the increasing demand for higher education and develop skilled, efficient and competent manpower the then Government felt the need for establishing private universities and approved the Private University Act 1992. Islam S. (2003) states that education was seen as the essential factors for rapid economic growth and formal education controlled by the state, as the indispensable instrument for improving the production capacities of a population. Most countries of the world are now facing the dilemmas of having to satisfy the need of the increased demand for education (Islam S. 2003). Higher education system needs to be flexible if they are to be the most effective (Muzaffar A.T. and Khan A.H. 2004). Education systems need to be able to adapt quickly to changing enrolment levels, to the rise and fall of different fields of study and to changes in the mix of skills demanded in the labor market. Muzaffar and Khan (2004) also argued that open systems are more likely to keep pace with significant external changes.

Field (1991) indicated that the marketplace philosophy will be a necessity in education. Matin M.A. (2003) mentioned that still there is the necessity of many more private universities in the country, but they must not be allowed to grow in an unplanned way'. It should be noted here that all the private universities operating in Bangladesh must take into account ethical considerations when developing their marketing plans and programs. Education providers provide various services to the students (customers) and they need to apply marketing tools and techniques at various levels. According to Kotler (1991) services marketing is '... any act of performance that one party can offer to another that is essentially intangible and does not result in the ownership of any thing...' However as Kotler goes on to argue, no product is sold within the market place without an element of 'service' which may comprise a major part of the actual offer. Giles (1990) suggests that in market economy countries, the service sector has increased more than other industries. Stanton (1978) and Cannon (1986) indicate that the service is the central point of any marketing, i.e. the precise 'product' that the business is selling. There is, therefore, a wide variety of definitions. Stanton (1981) omits areas, such as credit facilities, from his definition. However, education providers may include credit facilities as an optional strategy to boost their uniqueness and the range of benefits that they can offer to the customer (student).

\section{Objectives of the Research}

- To formulate opinion about the quality education in private universities.

- To bring into light the role played by the private universities in ensuring higher education in the country.

\section{Significance of the Research}

One of the aims of this study was to bring into light the contribution of private universities in the given task of nation-building. Found result indicated that the private universities are contributing lot to the development of the nation and expanding higher education in the country.

\section{Methodology of the Research}

Methodologies of research are given below:

\subsection{Materials}

The main source of data used was a field level survey conducted during the fall session of 2015 at some selected private universities in Dhaka. Those universities have all been in existence for at least ten years. A structured questionnaire was used in the survey. One common questionnaire was designed to elicit information on the contribution of private universities in Bangladesh. The questionnaire included 14 questions on various aspects of contribution of private universities like job market, learner's satisfaction, academic environment, session jam and quality of the existing teachers. Open-ended and close ended questions were used. The respondents of the survey were also allowed to pick more than one option (for preferred types) wherever necessary.

- Survey undertaken among the faculty members of private universities

- Use of secondary published sources

- Interview of persons involved in planning and updating higher education

\subsection{Participants}

Participants included 100 teachers from leading private universities of Bangladesh. The universities are:

- The Millennium University (TMU)

- Southeast University (SU)

- Stamford University (SU)

- State university of Bangladesh of Bangladesh (SUB)

- Atish Dipankar University of Technology (ADUST)

- Asian University of Bangladesh (AUB)

Among teachers were/ respondents were from

- Teachers from English Department.

- Teachers from Business Department.

- Teachers from CSE Department. 
The teachers were all instructors different existing private universities of Bangladesh. They were teaching both at graduate and postgraduate level. Noteworthy to say, that most of the teachers were professionally experienced and has been working in the private universities on a general range of 1-5 years.

The respondents were selected on the basis of merit and professional /excellence especially those who common general knowledge on the private universities and knowledgeable of the circumstances, academic environment, course curriculum of private universities.

\subsection{Procedure}

The respondents were given the questionnaire to fill out anonymously. Teacher's responses were collected within three working days. The students were given the questionnaire after class session and were requested to respond on research.

\section{Data Analysis and Findings}

Through the data analysis of the survey it has been found out that

I. All the respondents respond narratively to the first study, that was to tell a thing about the role of the private universities. The responses given by the participants are summarized below:

- Private universities have opened- up a new window for higher education.

- Its flourishment is necessary for the national growth \& development.

- Private universities are booming in Bangladesh become public universities do have limited space in comparison with growing / increasing number of students.

- The total duration of study in private universities is comparatively low in term of completion of degrees.

- Prospective candidate / students can enter into the job market very quickly as there is no session-jam in private universities.

II. Quality of education in Private University.

In this study, $64.71 \%$ respondents said that education system of private university is satisfactory. On the other hand $20.59 \%$ respondents said that education system of private university is not satisfactory.

III. The curriculums followed by the Private Universities.

Most of the respondents said that curriculums of private universities are approved by UGC. To face the global competition private universities regular update their syllabus.

IV. Private Universities should introduced a uniform grading system.

In this study, 52.94\% respondents said that all private universities in Bangladesh must follow a uniform grading system. On the other hand $26.47 \%$ respondents said that all private universities in Bangladesh should follow a uniform grading system.

V. Extra-curricular activities of the students.
Private universities are not only providing education at a minimal cost but also opened-up/ create new scope/ avenue for cultural nourishment/development of the students/ learners coming from varies strata of the society. All the $(100 \%)$ respondents are of the view, that their universities are engaged with various sorts of extra-curricular activities like-

- Debate competition

- Cultural exchange program

- Publishing news letter, magazines.

- Arranging annual picnic-program

- Sports of different types etc

VI. Applied modern technologies in the classroom.

Application of modern technologies: We wanted to see whether the teachers and students of private universities use modern technologies. $80 \%$ of the total respondents were imperative to these questions. Opinions are given below:

- Most of the private universities are equipped with modern technologies like computer, internet, and power point project.

VII. Positive sides of Private Universities

All the respondents said that private universities have advantages like the absence of strike so that there is no session jam, students get modern technologies oriented classroom, communicate with teachers easily.

VIII. Private Universities should introduce uniform admission test for enrollment.

In this study, $85.29 \%$ respondents said that all private universities in Bangladesh should introduce uniform admission test for enrollment. On the other hand $14.71 \%$ respondents said against this question.

IX. After completing the education of the students can make them successful in the job market.

To keep pace with modern world higher education in necessary and after completing the education, students can easily get and secure government job, in multinational companies and other non government jobs as well.

X. The students of Private Universities are enthusiastic for study.

The students of private universities are being attracted to study at private universities. Since there is almost no sessionjam in the private universities, it creates them enable to enter into competitive job market in a comparatively loss time than public universities. $40 \%$ of total respondents are argued that the general scenario the perception of students have changed about studying in private universities.

XI. M Phil, PhD course should be introduced in Private Universities for ensuring higher education.

Most of the respondents said that only the best private universities can introduce $\mathrm{M}$ Phil, $\mathrm{PhD}$ courses but not all the private universities should have permission to introduce.

XII. The scope of research in Private Universities.

Private Universities are also in march of research activities in the time with the public universities. Most of the private universities how public academic research, journals/ organizes seminar, symposium, conferences on various thematic issues like relating to acumen persist of the students and teachers. 
XIII. Government should select areas to fix up tuition fees for the students.

In this study, 91\% respondents gave opinion in favor of fixing up tuition fees for this student. On the other hand $9 \%$ respondents said against fixing up tuition fees.

XIV. A uniform salary system should be introduced for the teachers.

In this study, $85.29 \%$ respondents said that a uniform salary system should be introduced for the teachers. On the other hand $8.82 \%$ respondents said against this question. And $5.89 \%$ respondent does not answer this question.

\section{Recommendation}

Considering the rapid growth of private sector universities over a period of only 23 years, there are areas which need immediate attention by the providers and policymakers to improve service quality and to take these institutions in the next phase of development:

- Formation of an accreditation council composed of representatives of universities and faculties, regulatory bodies and other stakeholders. Recently, there has been talk of forming such a council under the auspices of the UGC (University Grant Commission). To my mind this would not be a good idea: the UGC today is not equipped to carry out such an important and challenging task with its existing capacity and organizational set-up. It is a fairly lethargic and bureaucratic organization, devoid of professional management and lacking in vision.

- More resources should be made available by the university, government and development agencies for the purpose of higher education and the training of faculty. International and regional academic institutions can extend assistance in this regard to help young academics.

- To be fair to students and parents, universities should not charge exorbitant fees to the students for the purpose of future university development and growth. Instead, each Board of Governors should mobilize others concerned, and raise expansion funds through donations or commercial borrowing.

- In general, the universities should have a quality control mechanism in place for admissions and subsequent processing of students, and adhere strictly to it.

- Proper career counseling and job placement are receives for a program me's long term success, and successful branding of good educational providers. Each university should focus attention on this vital issue.

- Collaborative efforts with foreign universities and other academic institutions demand much greater emphasis to be effective. The opportunities for regional collaboration should be explored further, which could be more effective and less costly for each.

- All private universities should follow or maintain an equal salary system because it could encourage teachers and switching of teachers from one university to another can be decreased. Through a uniform salary structure universities will get more experienced teachers.

\section{Conclusion}

This has been evident from the above research that the development of a country and its economy is dependent on the proper management of the contemporary issues and the success of such issues mostly depends on the development of well trained, educated and groomed human resources. In each of these cases higher study has been remained as a crucial factor over the years and the private university industry just like the other private initiatives of the economy is playing a major role in this context of Bangladesh.

Like the ready-made garments industry, which is the largest source of foreign exchange earnings for Bangladesh, private sector university education in this country has developed on its own with little support from the government. The time is now right for these universities to put their house in order and to move forward by adopting corrective measures that lead to quality education in a vibrant environment. Regional and global collaboration could boost private-sector education in Bangladesh. Promoters of private sector education should seek to raise funds from alumni, development partners and other stakeholders, rather than charging exorbitant student fees. By keeping fees low in this way, the private universities can service the less fortunate sections of the community, and thus help in bringing about a more balanced society.

In this research paper, we tried to find out the contribution of private universities in the arena of higher education in Bangladesh. The encouraging discovery was that truly, the private universities are contributing significantly in the higher education scenario in Bangladesh. On the contrary, the most prevalent shortcoming that was found out is that, some of the universities have limitations in flourishing fully the academic scenario and do not have policy for teachers' remuneration. Despite some limitations, through the study, it has been come out that private universities are significantly playing key-role in the expansion of higher education in the country.

\section{Annexure}

\section{Annexure-1}

\section{Survey Questionnaire}

The Role of Private Universities in Higher Education of Bangladesh: An Empirical Investigation

For the successful completion of this research; I need some information from you. I wish your kind cooperation and assistance. I can give the assurance that all information you would kindly give me will be used for research purpose only.

I. What is the role of Private Universities in higher education in Bangladesh? (Say briefly)

II. What is quality of education in Private University? 


\begin{tabular}{|l|l|l|l|l|}
\hline Best & Boot Good \\
\hline
\end{tabular}

III. Do you think that the curriculums followed by the Private Universities are updated?

IV. Do you think that Private Universities should introduce a uniform grading system?

\begin{tabular}{|c|c|c|c|}
\hline Must & Should & $\begin{array}{l}\text { Should } \\
\text { Not }\end{array}$ & Not at all \\
\hline
\end{tabular}

V. What sort of extra-curricular activities the students are engaged with in your universities?

VI. Do you apply modern technologies in the classroom of your University?

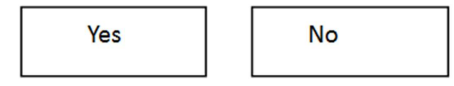

VII. What are the positive sides of Private Universities?

VIII. Do you think that Private Universities should introduce uniform admission test for enrollment?
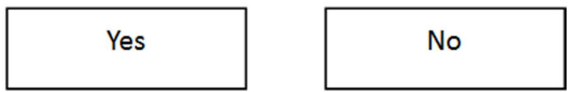

IX. Do you think that after completing the education the students can make them successful in job market?

X. Do you think the students of Private Universities are enthusiastic for study?
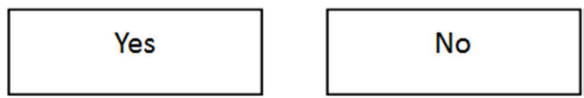

XI. Do you think that $\mathrm{M}$ Phil, PhD course should be introduced in Private Universities for ensuring higher education?

XII. What is the scope of research in Private Universities?
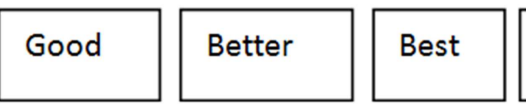

Not at all

XIII. Do you think that government should select areas to fix up tuition fees for the students?
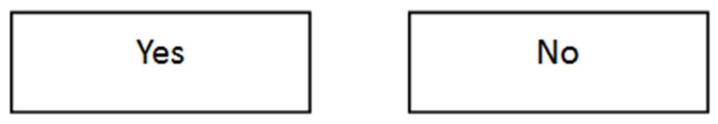

XIV. Do you think that a uniform salary system should be introduced for the teachers?

\section{References}

[1] Ansoff .I (1965), Corporate Strategy. McGraw-Hill, Maidenhead.Bangladesh Bureau of Statistics, in 1992

[2] Beaven M.H, Scotti DJ (1990) Service oriented thinking and its implications for the marekting mix J. Market 4: 5-19.

[3] Birks D.F (1991) Marketing research In: Baker M.J, ed. The
Marketing Book, 2nd ed. Butterworth- Heinemann, Oxford.

[4] Bateson J.E.G (1992) Managing Services Marketing: Text and Reader, 3rd ed, Dryden Press, London.

[5] Cannon T (1986) Basic Marketing: Principles and Practice. Holt. Rinehart and Winston, London.

[6] Cowell D.W (1991), Marketing services. in: Baker MJ, ed. The Marketing Book. 2nded. Butterworth -Heinemann. Oxford.

[7] Donabedian A (1966), Evaluating the Quality of Medical Care. Millbank Memorial Quality, London.

[8] Faltermeyer T.S (1994), Marketing Management. incorporating A Qualitative Research Study within Colleges of Midwifery and Nursing. Unpublished MSc Dissertation. University of Salford.

[9] Giles G.B (1990), Marketing 5 edn. Pitman Publishing, London.

[10] Gronross C (1984), A service quality model and its marketing implications. European Journal of Marketing 18 (4): 36-44.

[11] Islam S. A.K.M. (2003), 'An Education-Unfolding' in Observer Magazine, September 12.

[12] Kotler (1991), Marketing Management. Analysis, Planning, Implementation and Control, 7th ed. Prentice Hall, Englewood Cliffs.

[13] Kotler P, Armstrong G (1991), Principles of Marketing, 5th ed. Prentice Hall, Englewood Cliffs.

[14] Lovelock C.H (1981), Why marketing needs to be different. In Donnelly, JH, George WR, eds. Marketing of Services. American Marketing Association, Chicago.

[15] Levelock C.H (1984) Services Marketing Prentice-Hall, New Jersey

[16] Leppard J.W, McDonald MHB (1991) Marketing planning and corporate culture: A conceptual framework which examines management attitudes in the context of marketing planning. Journal of Marketing Management 7(3) : 213-25.

[17] Levitt T (1960), Marketing myopia, Reprinted in: Levitt T, ed. (1991), Levitt on Marketing. Harvard Business Review, Boston.

[18] McDonald M.H.B (1991), Planning the marketing function In: Baker MJ, ed. The Marketing Book, 2nd ed. ButterworthHeinemann, Oxford.

[19] Matin M.A. (2003), 'Education Economic Growth \& Our Private Universities' in Observer Magazine, May 30.

[20] Muzaffar A.T. and Khan A.H. (2004), 'Overcoming the Challenges in Higher Education in Bangladesh', in Observer Magazine, August 20.

[21] Octon C.M (1983), A re-examination of marketing for British non-profit organizations. European Journal of Marketing 17 (5): $33-43$

[22] Siddique M.A. B. (2005), 'On the Proposed Private University Act 2004' in Observer Magazine, February 25.

[23] Stanton W.J (1978), The Fundamentals of Marketing. McGraw Hill, Maidenhead. 
[24] Stanton W.J (1981), Fundamentals of Marketing. MGraw Hill, New York.

[25] Shostack G.L (1977), Breaking free from product marketing. Journal of Marketing 41 (2): 73-80

[26] Zeithaml V.A, Parasuraman A, Berry L.J (1990), Delivering Quality Service. Free Press New York.

[27] Alam, Khorsed,(1996).Procedures of Environmental Impact Assessment: Bangladesh Perspective, Development Review,9 (1\&2):41-64.

[28] Alam, Khorshed (2005), "The Environment and Policy Making in Bangladesh", Journal of Bangladesh Studies, Vol. 7, No 1.

[29] Bangladesh Agricultural Research Council Record(BARC http://www.barc.gov.bd/ObjFunc.htm

[30] Bangladesh Centre for Advanced Studies (BCAS) Record). (http://www.bcas.net/AboutBCAS/About_Index.html

[31] Bangladesh Education Commission Report: Dhaka 1974.

[32] Begum, A. \& Bhuyan, H. R. (May 2005). Education for Poverty Reduction: Achievements and Challenges. Paper Presented at the Seminar on National Budget for 2005-06 and PRSP on May 29, 2005. Dhaka: Bangladesh Institute of Development Studies (BIDS).

[33] Chowdhury, Masudul Hoq (2004), Environmental Education for Sustainability in Bangladesh, Paper Presented at Asia Pacific Environmental Education Seminar,11-14 February,2004, Kesennuma, Japan.

[34] Chowdhury, Masudul Hoq (2004), Community Based Environmental Education for Sustainable Development: The Case of Bangladesh, Working Paper at Bangladesh Academy for Rural Development (BARD).

[35] Center for Environmental and Geographic Information Services (CEGIS) http://www.cegisbd.com

[36] Department of Agricultural Extension (DAE) Record (1996), Government of Bangladesh.

[37] Government of Bangladesh (GoB) (2005), Education policy. Dhaka: Ministry of Education. Available: http://www.moedu.gov.bd

[38] Haque, Md. Maynul, Islam: Paribesh Sangrakhan O Unnayan (Protection and Development of Environment in Islam),Dhaka: Islamic Foundation Bangladesh,2007.

[39] Institute of Environmental Science (IES) Record, University of Rajshahi ( http:www.ru.ac.bd/ies)

[40] Jahan, S. and Rouf, M. A. (2007), "Spatial and Temporal Pattern of Urbanization in Bangladesh" In Jahan, S. Maniruzzaman K.M. (ed.), Urbanization in Bangladesh: Patterns, Issues and Approaches to Planning, Dhaka: Bangladesh Institute of Planners: 2007 .

[41] Khalequzzaman M. (1999) Environmental Stewardship: A Prerequisite for Sustainable Development in Bangladesh, Georgia Southwestern State University, Americus, GA 31709, USA.

[42] Ministry of Environment and Forest of Bangladesh Record www.moef.gov.bd/html/env_bangladesh/env_origin.html

[43] Mobassher, A., and M. H. Rashid, (1991): On the climatologically changing pattern of mean sea level pressure in Bangladesh. Chittagong University Studies, Part II: Science, 15.

[44] Mohammad, Noor (2009), Environmental Law in Higher Education of Bangladesh and Malaysia: An Approach for Sustainability Paper presented at $3^{\text {rd }}$ International Conference on Higher Education for Sustainable Development, 20-22 November, 2009 held at University Sains Malaysia, Penang, Malaysia.

[45] National Curriculum and Text Book Committee (1977), Report, Part 1(Primary Stage), Part II (Secondary Stage), Dhaka.

[46] NEMAP (1995) National Environment Management Action Plan (NEMAP), Volume Ia (Summary) \& II (Main Report), 1995, prepared by Ministry of Environment and Forest, Government of the People's Republic of Bangladesh.

[47] NAPA (2009), National Adaptation Programme of Action (NAPA), prepared by Ministry of Environment and Forest, Government of the People's Republic of Bangladesh, Dhaka.

[48] Sharafiuddin A.M. and A. Atiq Rahman (1994), Environmental Education and Awareness, Environment and Development in Bangladesh, (Part-1) University Press Limited, Dhaka, Bangladesh.

[49] Sharafuddin M.A. (1990), Towards Sustainable Development Environmental Awareness and Education in Bangladesh. Ministry of Environment and Forest and IUCN. Bangladesh

[50] Rahim, M. A. (1961), Social and Cultural History of Bengal, Vol. I, Karachi, Pakistan Historical Society.

[51] Ross, Lisa and Khan, Lopa (ed.) (1995), Environmental Education in Bangladesh at the Tertiary Level, Dhaka: BCAS

[52] Salequzzaman M. (1998), 'Environmental Science Discipline of Khulna University in a Brief', Souvenir of National Seminar on Coastal Environment and Energy Resources inBangladesh, 8-9 December 1998, Environmental Science Discipline, Khulna University, Bangladesh.

[53] Salequzzaman M. and J.K. Davis (2003), "Environmental Education and Environmental Management in Bangladesh", Environmental Informatics Archives, Vol I..

[54] Sharafiuddin A.M. and A. Atiq Rahman (1994), Environmental Education and Awareness, Environment and Development in Bangladesh, (Part-1) University Press Limited, Dhaka, Bangladesh.

[55] Sharafuddin A.M. (1990), Towards Sustainable Development: Environmental Awareness and Education in Bangladesh. A Background Paper Prepared for National Conservation Strategy of Bangladesh, Ministry of Environment and Forest, Government of the People's Republic of Bangladesh and National Conservation Strategy of Bangladesh.

[56] Salim, Ghulam Hossain (1975) Riyazu-s-Salatin, 2nd edition Jayyed Pess, Delhi India.

[57] Space Research and Remote Sensing Organization (SPARRSO) (http://www.sparrso.gov.bd/intro.html)

[58] Statistical Yearbook of Bangladesh (2008),28 ${ }^{\text {th }}$ Edition, BBS: Ministry of Planning Government of The people's Republic of Bangladesh. 
[59] The Financial Express. (2009). Saturday. September 5.

[60] United Nations (2002) Johannesburg 2002 Bangladesh Country Profile, pdf version //www.un.org/esa/agenda21/natlinfo/wssd/bangladesh.pdf .
[61] Van Hemert, M. et al. (1995), Reviving Links-NGO Experiences in Environmental Education and People's Participation in Environmental Policies, Both Ends/SME Milieu Adviseurs/IUCN. 